\title{
TINJAUAN KRIMINOLOGIS TERHADAP PELANGGARAN LALU LINTAS SECARA MASSAL DALAM MASA KAMPANYE PEMILU
}

\author{
A. Rahmah \\ Universitas Indonesia Timur
}

\begin{abstract}
The purpose of this study is to determine the factors that cause mass traffic violations during the election campaign period and efforts to overcome them by police officers against mass traffic violations during the election campaign period. This research is normative with field research where data collection is done by interview and questionnaire distribution to several parties related to the research topic, besides the author also conducts library research through related data and books relating to the research topic, furthermore the data obtained were analyzed qualitatively and presented descriptively. Based on the analysis, the authors conclude several things, among others: (1) Factors that cause mass traffic violations during the election campaign period are indisciplinary factors, lack of supervision, no sanctions are given, habits, factors of selfishness, participation and facilities and infrastructure. (2) Efforts made by the Makassar City Police Traffic Unit in handling mass traffic violations during the election campaign period are through two efforts, the first being preventive measures, by conducting socialization using print and electronic media, and making banners and posters on the streets that are considered strategic. Second, with repressive measures or actions, these efforts take the form of reprimands, speeding tickets, and confiscation.
\end{abstract}

Keywords: Criminologists, General Elections, Traffic, Violations.

\begin{abstract}
Abstrak
Tujuan dari penelitian ini adalah untuk mengetahui faktor-faktor penyebab terjadinya pelanggaran lalu lintas secara massal dalam masa kampanye pemilu dan upaya penanggulangan yang dilakukan aparat kepolisisan terhadap pelanggaran lalulintas secara massal dalam masa kampanye pemilu. Penelitian ini bersifat normatif dengan penelitian lapangan dimana pengumpulan data dilakukan dengan metode wawancara dan pembagian angket terhadap beberapa pihak yang terkait dengn topik penelitian, selain itu penulis juga melakukan penelitian kepustakaan melalui data-data yang berkaitan dan buku-buku yang berkaitan dengan topik penelitian, selanjutnya data yang diperoleh dianalisis secara kualitatif dan dipaparkan secara deskriptif. Berdasarkan analisis, penulis menyimpulkan beberapa hal, antara lain: (1) Faktor yang menyebabkan terjadinya pelanggaran lalu lintas secara massal dalam masa kampanye pemilu yaitu faktor ketidakdisiplinan, kurangnya pengawasan tidak ada sanksi yang
\end{abstract}


diberikan, kebiasaan, faktor egoisme, ikut-ikutan serta sarana dan prasarana. (2) Upaya yang dilakukan oleh Satuan Lalu Lintas Kepolisian Resor Kota Besar Makassar dalam menaggulangi pelanggaran lalu lintas secara massal dalam masa kampanye pemilu yaitu melalui dua upaya yaitu yang pertama dengan upaya preventif, dengan melakukan sosialisasi dengan menggunakan media cetak, maupun elektronik, serta membuat spanduk dan poster di jalan-jalan yang dianggap strategis. Kedua dengan upaya represif atau penindakan, upaya ini berupa teguran, tilang, serta penyitaan.

Kata Kunci : Kriminologis, Pelanggaran, Lalu Lintas, Pemilihan Umum.

\section{PENDAHULUAN}

Indonesia merupakan Negara demokrasi yang dimana kedaulatan berada di tangan rakyat dan dilaksanakan menurut undang-undang dasar. Makna dari kedaulatan berada di tangan rakyat dalam hal inilah bahwa rakyat memiliki kedaulatan, tanggung jawab, hak dan kewajiban untuk secara demokratis memilih pemimpin yang akan membentuk pemerintahan guna mengurus dan melayani seluruh lapisan masyarakat, serta memilih wakil-wakil rakyat untuk mengawasi jalanya pemerintahan. Perwujudan kedaulatan rakyat dimaksud dilaksanakan melalui pemilihan umum secara langsung sebagai saran bagi rakyat untuk memilih wakil-wakilnya yang akan menjalankan fungsi melakukan pengawasan, menyalurkan aspirasi politik rakyat, membuat undang-undang sebagai landasan bagi semua pihak di Negara Kesatuan Republik Indonesia dalam menjalankan fungsi masing- masing, serta merumuskan anggaran pendapatan dan belanja untuk membiayai pelaksanaan fungsi-fungsi tersebut.

Sesuai ketentuan Pasal 22 E ayat 6 Undang-undang Dasar Negara Republik Indonesia Tahun 1945, pemilihan umum untuk memilih anggota Dewan Perwakilan Rakyat (DPR), Dewan Perwakilan Daerah (DPD), dan Dewan Perwakilan Rakyat Daerah (DPRD), diselenggarakan berdasarkan asas langsung, umum, bebas, rahasia, jujur, dan adil setiap lima tahun sekali. Pemilihan umum dimaksud di selenggarakan dengan menjamin prinsip keterwakilan, yang artinya setiap warga Negara Indonesia dijamin memiliki wakil yang duduk di lembaga perwakilan yang akan menyuarakan aspirasi rakyat di setiap tingkatan pemerintahan dari pusat hingga ke daerah.

Dengan asas langsung, rakyat sebagai pemilih mempunyai hak untuk memberikan suaranya secara langsung sesuai dengan kehendak hati nuraninya, tanpa perantara. Pemilihan yang bersifat umum mengandung makna menjamin kesempatan yang berlaku menyeluruh bagi semua warga Negara tanpa diskriminasi berdasarkan suku, agama, ras, golongan, jenis kelamin, kedaerahan, pekerjaan, dan status sosial melalui pemilihan umum. Pemilihan umum 
selanjutnya disebut pemilu adalah sarana pelaksanaan kedaulatan rakyat yang dilaksanakan secara langsung, umum, bebas, rahasia, jujur, dan adil dalam Negara kesatuan Republik Indonesia berdasarkan pancasila dan UndangUndang Dasar Negara Republik Indonesia tahun 1945.

Dalam asas pelaksanakaan dan lembaga penyelenggaraan pemilu Pasal 4 poin (f) menyebutkan masa kampanye. Kampanye pemilu adalah kegiatan peserta pemilu untuk menyakinkan para pemilih dengan menawarkan visi misi dan program peserta pemilu. Kampanye pemilu dilaksanakan dengan prinsip bertanggung jawab dan merupakan bagian dari pendidikan politik masyarakat. Pelaksanaan kampanye pemilu di laksanakan sejak 3 (tiga) hari setelah calon peserta pemilu ditetapkan sebagai peserta pemilu sampai dengan dimulainya masa tenang.

Dalam pelaksanaan kampanye pemilu yang dilaksanakan oleh partai politik melibatkan banyak massa dan banyak kendaraan. Dimana seringkali dalam pelaksanaanya terjadi pelanggaran lalu lintas yang tidak hanya dilakukan oleh satu orang ataupun satu kendaraan saja, tetapi terjadi pula pada kendaraan yang lainya sehingga terjadi pelanggaran lalu lintas secara massal.

Pelanggaran lalu lintas dalam masa kampanye kerap terjadi bukan hanya karena ketidaktahuan pengendara mengenai berbagai peraturan dan rambu-rambu lalu lintas jalan, akan tetapi bisa saja terjadi karena adanya faktor kesengajaan, serta tidak adanya sanksi yang di berikan oleh aparat kepolisian dalam hal pelanggaran lalu lintas secara massal ini.

\section{PEMBAHASAN}

\section{A. Data Pelanggaran Lalu Lintas Saat Kampanye Pemilu}

Kampanye pemilu merupakan merupakan kegiatan peserta pemilu untuk menyakinkan para pemilih dengan menawarkan visi, misi, program peserta pemilu dan atau informasi lainya. Kampanye pemilu dilaksanakan dalam bentuk pertemuan terbatas, tatap muka dan dialog, penyebaran melalui media cetak dan media elektronik, penyiaran media radio dan/atau televisi, penyebaran bahan kampanye kepada umum, pemasangan alat peraba di tempat umum, rapat umum, debat public atau debat terbuka antara calon dan/atau, kegiatan lain yang tidak melanggar peraturan perundang- undangan. Kegiatan yang banyak melibatkan massa yaitu melalui tatap muka, atau sering juga disebut dengan kampanye terbuka. Proses ini banyak diikuti oleh berbagai kalangan guna mewujudkan bentuk dukunganya secara langsung kepada para peserta pemilu.

Dalam pelaksanaan kampanye terbuka sering melibatkan banyak kendaraan, baik kendaraan roda dua maupun roda empat, sehingga dalam pelaksanaanya, 
suatu partai politik harus menyiapkan konsep yang matang agar proses kampanye dapat berjalan dengan lancar.

pelanggaran yang lebih banyak dilanggar oleh peserta kampanye yaitu tidak menggunakan helm bagi kendaraan bermotor sedangkan pada kendaraan roda empat (mobil) bentuk pelanggaran yang dilakukan yaitu dimana memuat penumpang yang melebihi kapasitas kendaraan. Dan tiap proses kampanye pemilu yang lebih banyak atau dominan melakukan pelanggaran Lalu lintas yaitu kendaraan roda dua atau motor, sebab motor sangat fleksibel sehingga memudahkan pengendara untuk menghindari macet.

\section{B. Faktor-Faktor Penyebab Terjadinya Pelanggaran Lalu Lintas Secara Massal dalam Masa Kampanye}

Adapun faktor-faktor penyebab terjadinya pelanggaran Lalu lintas secara massal dalam masa kampanye yaitu:

1. Faktor ketidakdisiplinan (Indiscipline Factor)

Kedisiplinan dalam berlalu lintas sangat penting sebab disiplin berlalu lintas dapat menciptakan suasana lalu lintas yang aman dan tertib, namun bagi para peserta kampaye hal tersebut sulit untuk dilakukan sebab banyak peserta kampanye tidak tertib dan disiplin dalam berkendara. Kedisiplinan dalam berkendara dapat melahirkan suatu sikap yang taat terhadap aturan ataupun hukum yang berlaku.

2. Kurangnya Pengawasan

Pada dasarnya setiap kegiatan yang besar atau pun menurunkan banyak massa memerlukan izin dari pihak kepolisian berupa izin keramaian terutama dalam hal kampanye pemilu. Kampanye pemilu merupakan suatu kegiatan yang resmi yang akan melibatkan banyak massa dan banyak kendaraan yang akan berkumpul pada satu titik yang telah ditentukan.

Menurut Aiptu Syahrul (KAUR Mintu Bag.Lalu lintas) pihak kepolisian di turunkan pada titik-titik yang dianggap perlu serta banyaknya petugas yang di turunkan sesuai dengan perkiraan jumlah massa yang akan hadir. Akan tetapi massa yang hadir lebih besar dari jumlah anggota kepolisian yang di turunkan, sehingga massa dapat melakukan pelanggaran lalu lintas secara leluasa.

3. Tidak Adanya Sanksi yang Diberikan

Peserta kampanye melanggaran Lalu lintas sebabkan tidak adanya sanksi yang diberikan oleh aparat kepolisian dalam menindak lanjuti peserta kampanye pemilu yang melakukan pelanggaran lalu lintas, 
penindakan dilakukan setelah kampanye selesai bahkan hal itu belum efektif dilakukan oleh pihak kepolisian.

4. Faktor Kebiasaan

pelanggaran Lalu lintas secara massal dalam masa kampaye pemilu telah menjadi suatu kebiasaan yang dilakukan secara berulang oleh masyarakat sebab tidak adanya sanksi yang tegas yang mampu memberikan efek jera kepada para pelanggar, ini membuat masyarakat banyak melakukan pelanggaran Lalu lintas saat kampanye pemilu.

5. Faktor Egoisme

Pihak kepolisian sudah mengumumkan kepada partai politik dan para simpatisan agar tetap menjaga ketertiban selama proses kampanye terutama menaati peraturan lalu lintas, namun kenyataanya di lapangan banyak peserta kampaye yang melanggar peraturan Lalu lintas.

Partai politik hanya memikirkan kepentingan partai tanpa adanya kepedulian akan keselamatan dari para peserta kampanye sebab partai politik tidak menekankan kepada para simpatisan agar tetap mematuhi peraturan Lalu lintas yang dapat membahayakan diri para simpatisan itu sendiri.

6. Faktor Ikut-ikutan

seseorang melanggar peraturan lalu lintas saat kampanye pemilu di sebabkan karena ikut- ikutan dengan pengedara lainya.

7. Faktor sarana dan prasarana

Pelanggaran lalu lintas saat kampanye pemilu tidak hanya di pengaruhi oleh faktor kedisiplinan, kurangnya pengawasan, factor ikutikutan, egoisme dll, namun sarana dan prasarana yang mendukung proses berlalu lintas juga harus di perhatikan sehingga tercipta masyarakat yang dapat tertib berlalu lintas.

\section{Upaya Penanggulangan yang Dilakukan oleh Pihak Kepolisian}

Upaya yang dilakukan adalah sebagai berikut:

1. Upaya preventif, yaitu merupakan pencegahan sebelum terjadinya kejahatan. Dalam upaya preventif yang ditekankan adalah menghilangkan kesempatan untuk melakukan kejahatan.adapun upaya ini antara lain:

a) Melakukan sosialisasi melalui media cetak dan elektornik

b) Membuat spanduk dan poster di sepanjang jalan-jalan yang strategis.

2. Upaya Represif, upaya ini merupakan suatu tindakan yang dilakukan saat telah terjadi tindakan pidana/kejahatan yang tindakanya berupa penegakan hukum (law enforcemenet). Seiring dengan pelaksanaan 
penaggulangan pelanggaran lalu lintas secara massal yang dilakukan oleh peserta kampanye pemilu, maka perlu upaya penanggulangan yang bersifat represif. Upaya represif yang dilakukan yakni:

a) Penindakan dengan Teguran

b) Penindakan dengan Tilang

c) Penindakan dengan Penyitaan

Menurut Aiptu Syahrul, upaya ini diharapkan mampu menyelesaikan permasalahan dalam pelanggaran berlalu lintas saat proses kampanye, walaupun tidak sepenuhnya masyarakat dapat mematuhi hal tersebut namun dengan adanya sanksi diharapkan dapat memberikan peringatan terhadap mereka yang tetap melanggar Lalu lintas saat kampanye walaupun tahu akan sanksinya.

\section{PENUTUP}

\section{A. Kesimpulan}

Berdasarkan pembahasan diatas maka, disimpulkan sebagai berikut :

1) Pelanggaran lalu lintas secara massal dalam masa kampanye pemilu di sebabkan oleh beberapa faktor, yaitu faktor ketidakdisiplinan (indiscipline factor), kurangnya pengawasan, tidak adanya sanksi yang diberikan, faktor Kebiasaan, faktor egoisme, ikut-ikutan, serta sarana dan prasarana.

2) Upaya-upaya yang dilakukan oleh satlantas polrestabes Makassar dalam menaggulani pelanggaran lalu lintas secara massal dalam masa kampanye pemilu yaitu melalui dua upaya yaitu yang pertaman dengan upaya prefentif, dengan melakukan sosialisasi dengan menggunakan media cetak, maupun elektronik, serta membuat spanduk dan poster di jalan-jalan yang dianggap strategis. Ke dua dengan upaya represif atau penindakan, upaya ini berupa teguran, tilang, serta penyitaan.

B. Saran -Saran

1) Perlu adanya kordinasi yang lebih antara pihak kepolisian dengan perwakilan partai politik mengenai dalam hal menjaga ketertiban umum saat proses kampanye, sebab hal ini menyangkut kepentingan masyarakat umum.

2) Perlu adanya sanksi yang tegas yang dapat di berikan oleh peserta kampanye yang melanggar Lalu lintas saat proses kampanye terbuka, agar proses kampanye tidak dijadikan suatu tempat untuk melanggar Lalu lintas, melainkan kampanye pemilu dapat juga jadi moment untuk dijadikan percontohan berLalu lintas yang tertib dan baik. 


\section{DAFTAR PUSTAKA}

Achmad Ali. Menguak Teori Hukum dan Teori Peradilan. Jakarta: Prenada Media Group, 2009.

A.S Alam. Pengantar Kriminologi. Makassar: Pustaka Refleksi, 2010.

Ibnu Tricahyo. Reformasi Pemilu Menuju Pemisahan Pemilu Nasional dan Local. Malang: In Trans Publishing, 2009.

Jimly Asshiddiqie. Pengantar Ilmu Hukum Tata Negara, jilid II Sekretaris Jenderal dan Kepanitraan Mahkamah Konstitusi Republik Indonesia. Jakarta: MKRI, 2006.

Kamus besar bahasa Indonesia (edisi ketiga). Pusat Bahasa Departemen Pendidikan Nasional. Jakarta: Balai Pustaka, 2005.

Miriam Budiardjo. Dasar-Dasar Ilmu Politik (Edisi Revisi). Jakarta: PT. Gramedia Pustaka Utama, 2008.

M. Aziz, Noor. Pengkajian Hukum Tentang Pemilihan Kepala Daerah. Badan Pembinaan Hukum Nasional dan Kementerian Hukum dan Ham RI: Cililitan, 2011.

Rumidan Rabi"ah. Lebih Dekat dengan Pemilu di Indonesia. PT Rajagrafindo Persada: Jakarta, 2009.

Topo Santoso dan Eva Achjani Zulfa. Kriminologi. Jakarta: PT Raja Grafindo Perada, 2003. 